\title{
Priceless Enthusiasm: The Pursuit of Shauq in South Asia
}

\section{Kirin Narayan \& Muhammad A. Kavesh}

To cite this article: Kirin Narayan \& Muhammad A. Kavesh (2019) Priceless Enthusiasm: The Pursuit of Shauq in South Asia, South Asia: Journal of South Asian Studies, 42:4, 711-725, DOI: 10.1080/00856401.2019.1619530

To link to this article: https://doi.org/10.1080/00856401.2019.1619530

册Published online: 26 Jun 2019.

Submit your article to this journal $\pi$

Џll Article views: 109

Q View related articles $\sqsubset$

View Crossmark data $[\nearrow$ 


\title{
Priceless Enthusiasm: The Pursuit of Shauq in South Asia
}

\author{
Kirin Narayan and Muhammad A. Kavesh \\ Department of Anthropology, School of Culture, History and Language, College of Asia and the \\ Pacific, Australian National University, Canberra, ACT, Australia
}

\begin{abstract}
The concept of shauq or shauk connotes a passionate interest, galvanising individuals across South Asia to devote time, energy and resources beyond their expected social roles and towards particular chosen activities. This essay explores explications of shauq encountered in the course of field research on men's pigeon flying in Pakistan and village women's singing in India, situating insights from the field amid available scholarly literature on shauq. Shauq can make fieldwork the arena for a spirited transmission of knowledge. We explore how people express the well-being emerging from shauq, the sociality of shared interest, and why shauq can be dangerous.
\end{abstract}

\section{KEYWORDS}

India; Pakistan; pigeon flying; shauq; singing;

South Asia

'Pigeons eat a lot every day', Rafik mused as his pigeons wheeled above his roof in South Punjab, Pakistan. Calculating that the daily cost of bird feed was nearly four hundred Pakistani rupees (US\$4) - about a third of his earnings as a roadside kebab vendor-Rafik observed to Kavesh that pigeons reciprocated only with their droppings. Yet he insisted that following this passionate interest, or shauq, was worthwhile. 'I am helpless to my shauq', he confessed. 'Keeping pigeons brings me satisfaction and happiness. Pigeon flying is my love, and pigeons are my beloved. Day and night, I think about them. Outsiders might think that keeping pigeons makes for loss. But for me, it's love'.

'As long as there's life, everyone will have some sort of sukinni', Urmilaji observed in Kangra, northwest India, using the local Pahari dialect word for shauq. Sitting in an inner room of her village home, she was explaining the importance of singing to Narayan. Like many older village women who sang, Urmilaji interchangeably used the words shauq or sukinni to explain her love of songs and the sense of well-being this practice generated. At the same time that she emphasised the human need to pursue such zestful engagement, she freely acknowledged that different people's shauq might draw them towards entirely different sorts of activities and the cultivation of different sorts of knowledge. She frankly did not 
consider all shauq-driven pursuits as equal, adding: 'The special thing about songs is that they give you wisdom.

This essay was inspired by a conjunction we discovered between the very different research interests of the two authors. Neither of us had gone to the field intending shauq to be a primary category of analysis. Yet the Muslim male pigeon flyers who taught Kavesh about pigeon flying and the elderly Hindu women singers who took charge of Narayan's education on songs both depicted their absorbing preoccupations as shauq: the word encompassed the psychological draw to a cultural domain, and also the performance of associated activities. While our rural field sites had, until Partition in 1947, been part of the same administrative state of Punjab, the similar emphasis on shauq that we encountered cannot simply be explained by a regional connection. Trying to make sense of overlaps and divergences in the ways in which our mentors spoke so eloquently of shauq in their lives, we revisited our field materials from fresh angles, and consulted the insights of other scholars describing shauq in various locations across South Asia. In this essay, we build on our comparative materials to better understand shauq from various insider and scholarly perspectives. While we point to resonances with other concepts, we refrain from reducing the complex dimensions of shauq to any single translation or theoretical framework.

We have organised this essay into four sections. First, we establish some of the parameters and key dimensions of shauq through a literature review. Second, we explore the ways in which individuals describe the deep fulfilment generated by absorption in such passionate pursuits. Third, we trace how emergent communities based around a shared interest are key to the transmission of specialised knowledge and skills. Fourth, we explore the limits of shauq in terms of individual engagement, societal disapproval and historical change. In conclusion, we underscore the ongoing relevance of shauq in contemporary South Asia.

\section{The span of shauq}

Spelled variously as shauq, shauk, sowq, sok, sokh-and with variants like sukinni ${ }^{1}$ this concept reappears across South Asia. In light of its etymology, we draw on the spelling 'shauq', except in direct attributions or quotations from authors who use an alternate form. The word derives from the Arabic šauq (pl. ašwāq), ${ }^{2}$ which means 'longing, yearning, craving, desire, wish'; the associated meanings clustering around the root $\check{s} \bar{a} q a$ also emphasise the pleasurable source of these strong feelings: 'to please, delight... give joy.... .3 Beyond South Asia, cognate words can be found in various Asian, Middle Eastern and African languages: Persian shouq or shough, Indonesian

1. This perhaps derives from shauqini defined as 'enthusiasm (for a pursuit)', appearing close after shauq. See R.S. McGregor, The Oxford Hindi-English Dictionary (Delhi: Oxford University Press, 1993), p. 957.

2. The derivatives of the word are šäiq (desirous), tašwīq (arousing/awakening of excitement), ištiyāq (longing, yearning), mušawwiq (stimulating, stirring) and muštāq (craving, covetous). It is worth noting that the Arabic word šauq should not be confused with a very similar šauk (ending with $k$ rather than $q$ ) meaning throne, spines, spikes, fishbone and fork. See Hans Wehr, A Dictionary of Modern Written Arabic (Urbana, IL: Spoken Language Services, Inc., 1979), p. 577; and Rohi Baalbaki, A Modern Arabic-English Dictionary (Beirut: Dar El-IIm Lilmalayin, 1995), p. 681.

3. Wehr, A Dictionary of Modern Written Arabic, p. 577. 
syauk, Swahili shauku, Tajik shavq and Turkish sevk. ${ }^{4}$ Interestingly, in colonial India, 'shoke' was listed in Hobson-Jobson's dictionary of Anglo-Indian colloquial words and defined as 'a hobby, a favourite pursuit or whim'. 5

Embarking on the scholarly trail of shauq, the earliest ethnographic account that we located is from Afghanistan. Ethnomusicologist Mark Slobin, working with musicians of diverse ethnicities in northern Afghanistan in the late 1960s and early 1970s, locates music amid the various pursuits that village men labelled as šowqi (shauq-based):

Gambling of all sorts (dice, cards, casting sheep bones)

Collecting any sort of object, but particularly such things as weapons

Raising, training and fighting various animals (quails, partridges, roosters, dogs, camels)

Collecting snakes, lizards, and scorpions

Admiration and raising of flowers

Kite flying, wrestling, and other sports

Decorating objects lavishly (radios, musical instruments, cars, trucks, horse-carts, etc.)

Patronizing favourite dancing boys or female entertainers

Playing a musical instrument as an amateur ${ }^{6}$

Games, collections, gardening, decorating, pursuing romantic infatuations, musicmaking-at first glance this appears a startlingly diverse list! Yet, as Slobin goes on to comment, 'The thread running through these diverse activities is the inner state that leads the individual to indulge in them ... pleasure, affection and predilection seem nearest the mark'. ${ }^{7}$ He describes music as a šowqi interest that 'lies somewhere in the zone between a hobby and an obsession and can perhaps best be described as a preoccupation with certain objects or activities, but one that does not constitute the individual's principal job or determine his station in life'. Afghans exhibiting shauq are described as 'dilaš zende ast' ('his heart is lively'). ${ }^{9}$ In this early account, Slobin underlines what we find is a recurring association of shauq with activities that are tangential to an individual's central form of livelihood, yet enrich their inner lives. Shauq, then, appears to resonate well with the wider sociological concept of serious leisure. ${ }^{10}$

Another ground-breaking body of work engaging shauq is Nita Kumar's historically grounded ethnography of the popular culture of artisans in Banaras. Even as

\footnotetext{
4. András Rajki, 'Arabic Etymological Dictionary' (2005) [https://www.academia.edu/4847281/Arabic_Etymological_ Dictionary, accessed 11 Mar. 2017].

5. Henry Yule and Burnell Coke, A Glossary of Anglo-Indian Colloquial Words and Phrases, and of Kindred Terms (London: John Murray, Albemarle Street, 1886), p. 831.

6. Mark Slobin, Music in the Culture of Northern Afghanistan (Tucson: University of Arizona Press, 1976), p. 23.

7. Ibid., p. 24.

8. Ibid.

9. Ibid.

10. Robert A. Stebbins, 'Serious Leisure: A Conceptual Statement', in The Pacific Sociological Review, Vol. 25, no. 2 (1982), pp. 251-72. See also Robert Stebbins, Serious Leisure: A Perspective for Our Time (New Brunswick, NJ/ London: Transaction Publishers, 2015); and Robert A. Stebbins, Careers in Serious Leisure: From Dabbler to Devotee in Search of Fulfilment (New York: Palgrave Macmillan, 2014).
} 
they struggled with poverty, Hindu and Muslim artisans devoted time and energy to a range of leisure activities representing their personal shauq: for example, going outdoors to bathe, wrestling, joining musical groups and participating in festivals. ${ }^{11}$ Kumar characterises the nuances of shauq in such ways as 'personal choice and passion', ${ }^{12}$ 'taste for/love for', ${ }^{13}$ 'hobby, weakness, passion'14 and 'intense love for an activity for its own sake. ${ }^{15}$ Viewed as 'personal compatibility based on taste and choice, ${ }^{16}$ shauq thus inspires social organisations around shared interests. 'As Banarsis themselves argue, what matters ultimately is shauk', writes Kumar, ${ }^{17}$ and in Banaras, the variability of shauk is taken seriously; the entertainment a person chooses is, when brought down to the basics, a part of his personality and nature'. ${ }^{18}$ Tracing the historically-changing patterns around how Banarsis have chosen to spend their leisure time, Kumar shows that as values change, so do the activities associated with shauq, and when certain activities dwindle, it is said that people no longer have that shauq. ${ }^{19}$ Interestingly, the lens of shauq was also turned on her own ethnographic activities: as she moved around Banaras for dissertation research, local people explained her 'meetings and wanderings that they found difficult to categorise, [as] "Shauk hai" ("it's her hobby, her fancy"). ${ }^{20}$

In the guise of various regional pronunciations and spellings, shauq finds mention in the work of many other scholars, whether in relation to traditional sports and pastimes $^{21}$ that include men's musical activities such as Muharram ritual drumming in Lahore, ${ }^{22}$ tabla (drum) playing in Lucknow ${ }^{23}$ and wrestling ${ }^{24}$ or biraha singing groups in Banaras. ${ }^{25}$ While most accounts of shauq to date highlight the perspective of men, scholars have recorded such passionate interests among women too, whether to acquire

11. Nita Kumar, 'Open Space and Free Time: Pleasure for the People of Banaras', in Contributions to Indian Sociology: New Series, Vol. 20, no. 1 (1986), pp. 41-60.

12. Ibid., p. 58.

13. Nita Kumar, The Artisans of Banaras: Popular Culture and Identity, 1880-1986 (Princeton, NJ: Princeton University Press, 1988), p. 88.

14. Ibid., p. 251.

15. Nita Kumar, 'Work and Leisure in the Formation of Identity: Muslim Weavers in a Hindu City', in Sandria B. Freitag (ed.) Culture and Power in Banaras: Community, Performance, and Environment, 1800-1980 (Berkeley/Los Angeles/Oxford: University of California Press, 1989), p. 168.

16. Kumar, The Artisans of Banaras, p. 202.

17. Ibid., p. 122.

18. Ibid., p. 136.

19. Kumar, 'Work and Leisure in the Formation of Identity', p. 187.

20. Nita Kumar, Friends, Brothers, and Informants: Fieldwork Memoirs of Banaras (Berkeley/Los Angeles/London: University of California Press, 1992), p. 20.

21. Jurgen Wasim Frembgen and Paul Rollier, Wrestlers, Pigeon Fanciers, and Kite Flyers: Traditional Sports and Pastimes in Lahore (Karachi: Oxford University Press, 2014), p. 58; and G. Whitney Azoy, Buzkashi: Game and Power in Afghanistan (Philadelphia: University of Pennsylvania Press, 1982), pp. 8-11.

22. Richard K. Wolf, 'The Manifest and the Hidden: Agency and Loss in Muslim Performance Traditions of South and West Asia', in Kamal Salhi (ed.), Music, Culture and Identity in the Muslim World: Performance, Politics and Piety (New York: Routledge, 2013), p. 152.

23. James Kippen, The Tabla of Lucknow: A Cultural Analysis of a Musical Tradition (Cambridge: Cambridge University Press, 1988), p. 133.

24. Joseph S. Alter, The Wrestler's Body: Identity and Ideology in North India (Berkeley: University of California Press, 1992), p. 155; and Joseph S. Alter, 'The "Sannyasi" and the Indian Wrestler: The Anatomy of a Relationship', in American Ethnologist, Vol. 19, no. 2 (1992), pp. 327-8.

25. Scott Marcus, 'The Rise of a Folk Music Genre: Biraha', in Sandria B. Freitag (ed.), Culture and Power in Banaras: Community, Performance, and Environment, 1800-1980 (Berkeley/Los Angeles/Oxford: University of California Press, 1989), p. 101. 
embroidery skills, ${ }^{26}$ to adorn themselves ${ }^{27}$ or to sing. ${ }^{28}$ We learn too that, among Nepali middle-class youth, 'doing fashion' is attributed to 'sokh'. ${ }^{29}$

Key to the conception of shauq is choice: people embrace an activity because they want to, not because they have to. Amid the hierarchies of South Asian society and social expectations for appropriate caste, kinship and gender roles, shauq can represent a delightful space of action opened by an interest rather than duty or financial exigency. This is not to say that expected duty might not sometimes become an arena of shauq-as with Kangra singers, who sang at the ritual songfests where women were supposed to sing, and then sang for their own pleasure as well. An activity chosen from shauq might also come to generate monetary gain, for example, when a South Punjabi man sold his specially bred pigeons or won competitions with them. Generally, shauq appears to stand in uneasy relation to financial need. Women in the Lucknow chikan embroidery industry, for example, repeatedly contrasted being drawn to embroidery from shauq as opposed to financial troubles (pareshani), emphasising how shauq took a back seat 'when a woman must regard chikan as a sole means of support, or a source of money to supplement a husband's meagre income'. ${ }^{30}$ Such an opposition between those who follow a practice because of their open choice of shauq rather than because they must earn is especially marked in ethnographies of musicians in north Pakistan and Afghanistan. ${ }^{31}$ As Sakata explains, amateur musicians emphatically distinguish themselves from hereditary paid professionals, who are considered to be of low and dubious status: 'Shauqi... denotes one who does anything because of a strong interest, inclination or desire to do so, but is not economically dependent on these acts'. 32

Two further permutations to the word are worth mentioning: shauqeen and shauqiya. A person who has a shauq, and particularly someone with refined tastes, might be termed a 'shauqeen'. A discerning engagement marks shauqeen people-for instance, those who gather to listen to a musical performance, ${ }^{33}$ women appraising and adorning themselves with beautiful clothes and jewellery, ${ }^{34}$ the audience for a wrestling match, ${ }^{35}$ or people watching and participating in polo. ${ }^{36} \mathrm{~A}$ person carried away by the pleasures

26. Clare M. Wilkinson-Weber, Embroidering Lives: Women's Work and Skill in the Lucknow Embroidery Industry (Albany: State University of New York, 1999), pp. 132-4.

27. Pravina Shukla, The Grace of Four Moons: Dress, Adornment, and the Art of the Body in Modern India (Bloomington/Indianapolis: Indiana University Press, 2008), pp. 275-6.

28. Kirin Narayan, Everyday Creativity: Singing Goddesses in the Himalayan Foothills (Chicago, IL/London: The University of Chicago Press, 2016).

29. Mark Liechty, Suitably Modern: Making Middle-Class Culture in a New Consumer Society (Princeton, NJ/Oxford: Princeton University Press, 2003), p. 81.

30. Wilkinson-Weber, Embroidering Lives, p. 134.

31. Magnus Marsden, Living Islam: Muslim Religious Experience in Pakistan's North-West Frontier (Cambridge: Cambridge University Press, 2005), p. 130; Magnus Marsden, 'Muslim Village Intellectuals: The Life of the Mind in Northern Pakistan', in Anthropology Today, Vol. 21, no. 1 (2005), pp. 10-5; John Baily, Music of Afghanistan: Professional Musicians in the City of Herat (Cambridge: Cambridge University Press, 1988), p. 143; and John Baily, 'Amin-E Diwaneh: The Musician as Madman', in Popular Music, Vol. 7, no. 2 (1988), pp. 133-46.

32. Hiromi Lorraine Sakata, Music in the Mind: The Concepts of Music and Musician in Afghanistan (Kent, OH: Kent State University Press, 1983), p. 84.

33. Slobin, Music in the Culture of Northern Afghanistan, pp. 24-5.

34. Shukla, The Grace of Four Moons, p. 205.

35. Alter, The Wrestler's Body, p. 177.

36. Peter Parkes, 'Indigenous Polo in Northern Pakistan: Game and Power on the Periphery', in James H. Miller (ed.), Subaltern Sports: Politics and Sport in South Asia (London: Anthem Press, 2005), p. 72. 
of shauq may also be labelled a 'shauqiya'. For example, Joseph Alter contrasts the 'shaukiya wrestler-preoccupied with pleasure and aesthetic self-gratification' to selfdisciplined wrestlers: while both may wrestle, 'they differ fundamentally in their perception of how what they do relates to who they are. ${ }^{37}$

A fieldworker's interest in a particular cultural domain, we found, could be interpreted through the lens of shauq. We have already mentioned how Nita Kumar's informants accepted her uncategorisable wanderings as her own peculiar shauq; obversely, participating in an activity categorised as shauq could result in fieldwork being viewed as shauq-driven, distinct from a studious academic identity. For example, when, in the course of researching Lucknow chikan embroiderers, Clare WilkinsonWeber began sewing herself, 'the explanation that I had shauq was usually sufficient to explain why I was spending so much time in the neighbourhood and why I was learning the craft'. ${ }^{38}$ For us too, doing fieldwork in our respective locations, the perceived commonality of shauq generated rapport. We were warmly welcomed, enthusiastically included in activities, given tips for further research, and educated in specialised domains of knowledge. Men introducing Kavesh to fellow enthusiasts vouched for him not through his family or educational background, but as someone who 'knows different breeds of pigeons and can differentiate them by their colours'. Pigeon flyers invited him to various pigeon competitions, introduced him to other flyers, and shared words from the specialised vocabulary that was occasionally used to exclude outsiders from their pigeon flying circles. Similarly, women singers in Kangra villages interpreted Narayan's sustained interest in recording their songs since the early 1980s as a manifestation of a mutually shared shauq. They invited her to ritual events where songs would be sung, and improvised occasions to educate her by informally sharing and discussing songs. The ability to sing (geet gaana) was also connected with inciting others to sing (geet gawaana), and so singers who took charge of Narayan's research not only decided what precious materials to themselves share, but also elicited choice songs from other nearby singers, and planned outings to record singers in other villages. Both Kavesh and Narayan were also eloquently instructed on what people most valued about shauq.

\section{The inestimable value of shauq}

Nadir Abbas retired early from his teaching job partly to devote more time to his birds. 'Whenever I see a beautifully coloured pigeon, I get it at any price because...', he paused to indicate that he was about to quote a proverb, 'shauq is priceless (shauq $\mathrm{ka}$ koi mol nahin)'. He confessed that though his wife complained that he was busy with his pigeons all day, he was unable to change his ways: 'I've told her that I will accept anything she says, but I cannot leave this shauq. By looking at pigeons, I forget about my sorrows (gham). If I go away to another city, I try to come back early because of my pigeons'.

The same emphasis on shauq's priceless (anmol) value was expressed in another popular saying: 'Written accounts aren't kept for shauq (shauq de wich lekhy ne

37. Alter, 'The "Sannyasi" and the Indian Wrestler', p. 327.

38. Wilkinson-Weber, Embroidering Lives, p. 133. 
karende)'. Despite their poverty, pigeon flyers keep investing in pigeons and their care. Abbas' words, emphasising the pigeon's colourful beauty, at first appear to highlight the value of aesthetic pleasure over pragmatic considerations. Pigeon flyers bought pigeons that caught their eye, and they systematically mated pigeons with the intention of producing uniquely patterned birds. Especially prized was a lal chap-a pigeon with one white and one red wing that could be immediately identified in the air and on the ground. Flyers also adorned their pigeons, tying musical anklets and colourful beads onto their feet to enhance their beauty (khoobsoorti).

Similarly, Kangra women singers emphasised the attraction and beauty of particular songs. Women who experienced singing as their passionate sukinni or shauq were those who took charge at celebrations for which women's chorused songs were thought to bring good fortune. They led others through songs they particularly cherished. They also urged others to sing, complimenting their beautiful voices and their knowledge of particular beautiful (suhaana, chail) songs. The moving emotions expressed in stories retold through song were seen as beautiful, and songs were appreciated both for their poetic language and their melodies. As Asha Devi said: 'Songs are beautified by their melodies'. The verb 'sajaana', translated as 'to beautify', also means to adorn.

Might shauq then be viewed as a form of aesthetic adornment in sociologist Georg Simmel's terms? Adornment, Simmel argues, is not pragmatically essential; however it 'intensifies or enlarges the impression of the personality', ${ }^{39}$ and by displaying materials that are aesthetically valued in style and in substance by a group, also carries 'the sociological charm of being, by virtue of adornment, a representative of one's group, with whose whole significance one is "adorned"' ${ }^{40}$ While a source of personal pleasure that affirms a person's agency, efficacy and imaginative possibility, shauq also reveals the aesthetics and values elaborated within particular self-chosen social groups.

But adorning everyday life with aesthetic pleasure only appears to partially explain the compelling aspect of shauq. Nadir Abbas' admission that pigeons helped him forget his sorrows points to a larger association of shauq with positive states of being. In South Punjabi villages and in Kangra villages, enthusiasts of shauq described their activities as gladdening the heart ( $d i l)$ and the mind (man). Flyers took daily pleasure in their connection with their birds, whistling and directing their birds to rise together into the sky. Pigeons were also said to open out the world of the imagination (khayaali duniya) beyond the proximate anxieties of daily life. Flying high in the sky and sometimes out of sight in the ether, pigeons 'came near Allah'. Furthermore, the birds'

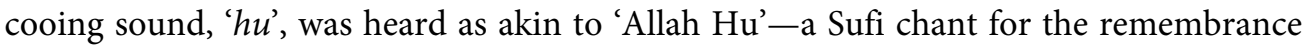
of God (zikr), and so birds carried a symbolic association with Sufi shrines and mosques. ${ }^{41}$

The well-being emerging from shauq, we both observed, connected partly with social psychologist Mihaly Csikszentmihalyi's concept of 'flow'-that is, the complete and satisfying attention associated with tasks through which the sense of

39. Georg Simmel, The Sociology of Georg Simmel (New York: The Free Press, 1950), p. 349.

40. Ibid., p. 343.

41. It is worth noting that in Sufi Islam, shauq is cast as a 'mystical or spiritual state associated with the longing to contemplate the divine beloved'. See John Esposito, Shauq, in John Esposito (ed.), The Oxford Dictionary of Islam (Oxford/New York: Oxford University Press, 2003), p. 290. 
a bounded self might disappear. ${ }^{42}$ The absorbing focus of staying connected to so many birds, like the attention needed to recall a song's many verses, offered immediate satisfaction while imaginatively transporting an individual beyond everyday constraints. In Kangra, Narbada Devi observed: 'One is trapped by all these ties and sometimes one's mind is filled with sorrow. Then when one sings a beautiful song it brings happiness to one's mind. All the sorrows go far away'. ${ }^{43}$ This happiness (khushi, anand, prasannata) for women was also illumined by contact with transcendent dimensions when goddesses' and gods' stories were retold through song - a divine presence summoned by singing.

Honing skills, gathering knowledge and gaining status within a community of shauq was also deeply satisfying and a possible mode of lifelong learning. White-haired Subhadra Devi, like other women of her generation, had not had the chance to finish school, yet all her life she had enjoyed and expanded on a repertoire of many sorts of songs. She sang while cooking, washing and doing other tasks, and compared her need for songs to other types of addiction: 'Those who drink liquor will drink', she said, laughing. 'Those who must have tea will have tea. Those who sing will sing. It's a form of addiction'. As she said, 'The more you sing, the more you have to sing. One song comes out after another song. However sad we are, whatever has happened in our lives, when we sit to sing we're happy again'. ${ }^{44}$ Yet she also acknowledged that this feeling was peculiar to fellow enthusiasts, adding: 'Those who don't sing don't know how this is. ${ }^{45}$

In describing the compelling power of shauq in their lives, pigeon flyers sometimes stated that they wore 'the bangles of shauq (shauq diyan wangan)'. Only women wore bangles as a form of adornment in South Punjab's strongly patriarchal society. In saying that they wore the bangles of shauq, men seemed to be pointing to two important aspects of their engagement. First, they acknowledged being feminised, with bangles representing a domestic shackle. For pigeon flyers, this meant the responsibilities of caring for pigeons and an associated restriction on their mobility. Pigeons required 'love like a mother's' as flyers cleaned pigeon coops, prepared the birds' food, cured them when ill, and arranged their comfort in the extreme temperatures of summer and winter. Second, the reference to bangles emphasised how shauq added beauty and pleasure to everyday life.

\section{The sociality of shared interest}

To pursue shauq one must have exposure or access to a community. For some, the cultivation of shauq emerges within a familial setting. Rafik, the kebab seller whose words opened this essay, emphasised how his father, his uncle, and now two of his sons all shared this shauq. Describing themselves as khaandaani shauqia (generational enthusiasts), pigeon flyers claimed this as their birthright, while also signalling a prestigious connection with past rulers who had been known to keep pigeons: local nawabs and

42. Mihaly Csikszentmihalyi, Flow: The Psychology of Optimal Experience (New York: Harper \& Row, 1990), p. 49.

43. Narayan, Everyday Creativity, p. 212.

44. Ibid., p. xix.

45. Ibid., p. 182. 
Mughal kings. ${ }^{46}$ While many Kangra women mentioned their older female relatives as important influences in cultivating their interest and knowledge, the movement of women due to marriage meant that they carried songs across families and between villages.

Yet shauq is not just contained within families. The mastery of fine shades of categorisation, specialised meanings and particular skills associated with a shauq could gain a person great respect, drawing others to learn from them. While Kangra women singers might be praised as 'badi gyaani' (very knowledgeable) or 'badi raagin' (very musical), the informality of transmission during songfests meant that these experts were only playfully referred to as 'gurus' or teachers. A knowledgeable woman controlled a large repertoire of songs and could summon up the appropriate songs for an occasion, and even the particular steps of ritual; she could competently lead others through words and melodies. In South Punjab, an exceptionally knowledgeable pigeon flyer could become known as a skilled master, or ustaad, who transmitted specialised knowledge to a disciple (shagird). Ustaads were experts on different breeds of pigeons. They taught their disciples ways to identify particularly good pigeons, to pair pigeons to ensure the best offspring, to adapt diet to different seasons, and to mix herbs for healing sick pigeons. They also extended advice before and during pigeon flying competitions. A disciple's successes reflected positively on the ustaad.

While neither singing nor pigeon flying involved akharas as formal associations, it is worth noting this formal grouping around shauq in other regions. Nita Kumar characterises akharas in Banaras thus: 'They all have gurus or ustads (teachers); what they teach is vidya kala (specialised knowledge, art); what the students must have is shauk (passion); and what they must do to learn the art is riyaz (regular practice)'. ${ }^{47}$ Joseph Alter's ethnography of wrestlers brings akharas into focus as gymnasia in pleasing physical locations, bringing high- and low-caste groups together for practice under the tutelage of a teacher (guru). ${ }^{48}$ Similarly, in his accounts of the genre of biraha musical performances in Banaras, Scott Marcus has shown how songs might belong to the akhara, and the identity gained through associating with an akhara becomes especially salient during competitive singing events. ${ }^{49}$

Even without identification with an akhara, close relationships could develop through shared interest. Pakistani village men who formed friendships around pigeon flying used the term 'yaari' (close friendship) to emphasise the deep affection of their relationship. Pigeon flyers who were yaar (friends) were said to develop an intimate understanding of each other's emotions and feelings. They helped each other in many ways: breeding pigeons, consulting on pigeons' dietary and medical needs, and launching pigeons into competitions. They celebrated each other's successes and losses. Men often drew on sayings that celebrated this sort of amity: 'Among friends there is

46. Many Mughal rulers cultivated an interest in keeping pigeons. Emperor Akbar (1542-1605) kept almost 20,000 pigeons of different breeds at his court. Abul Fazl (author of the Ain-i-Akbari) wrote a separate chapter on 'ishqbāzī' (love-play), explaining the emperor's fascination with pigeons. See Abul Allami Fazl, Ain-i-Akbari, Vol. 1, M.A.H. Blochmann (trans.) (Calcutta: Baptist Mission Press, 1873), pp. 298-303.

47. Kumar, The Artisans of Banaras, p. 111.

48. Alter, The Wrestler's Body, pp. 2, 26-57.

49. Marcus, 'The Rise of a Folk Music Genre', pp. 96-7. 
springtime (yaaran naal bahaaran)' and 'Every sacrifice for friendship (yaari tey sab qurban)'.

Songfests most often brought together women relatives and also sometimes neighbours of roughly equivalent caste status: groups who might refer to each other through kinship terms or more broadly as 'sisters' (bahna). Singers also sought out songs beyond the groups that assembled for customary songfests. Judhya Devi, who was in her fifties, described her passion:

I'm always singing. I love songs. Even when I'm working, I keep singing something or the other. People passing by always say, 'That's Rashmi's mother singing'-Rashmi is my eldest daughter. I'm interested in all sorts of songs. I listen everywhere I go. If I hear Chamar women sing something in the fields, I go sit there and make them repeat it so I can listen. I've learned all the dholru (basket-maker's ballads) too, by sitting down with the Dumnas and listening to their songs. I can hear a song once, and it goes and sits inside me. I remember all the words and the tune. Yes, I have a real sukinni (shauk) for singing! $!^{50}$

Though of the dominant Rajput caste, Judhya Devi sought out other singers across caste boundaries because she admired their songs: lower-caste Dalit women who sang while transplanting rice, and the Dalit basket-maker men and women who went between courtyards each spring, singing dholru ballads about women's suffering for which they received grain and alms. The compelling interest of shauq could thus result in a high-caste person seeking out interactions outside the expected caste hierarchy. Notice, however, in these examples, that the interaction was initiated by a higher-caste person and occurred in the outer space of fields and courtyards. For a person of a lower caste, it would be extremely difficult to gain direct access to the specialised repertoire of higher-caste singers within a household. Yet in one village, an expert, melodious singer from the barber caste was often asked to join Brahman women's songfests. She took great pride in the respect she was shown by this inclusion, and the new songs that she continually learned.

For Pakistani pigeon flyers too, shared interest around shauq could, within that domain, level other social categorisations. Ustaad Jameel, a poor man in his late sixties who sometimes instructed wealthier pigeon flyers, reflected: 'In pigeon keeping everyone is equal. Rich and poor: all are equal to each other. They sit together and share this shauq'. Similarly, Haqnawaz, a middle-aged man of the potter caste, was regularly invited by an affluent and politically influential local man to chat about pigeon flying. In addition to these movements across caste and class, Wilkinson-Weber has noted how, in Lucknow's embroidery industry, mostly controlled by Muslims, it is shauq that matters, not religions $:^{51}$ thus, when some Hindu girls and she herself expressed a passion for learning embroidery, Muslim teachers (ustads) shared their knowledge with them. In all these cases, it is not clear whether the apparent loosening of social differentiation within the domain of shauq carries a lasting effect into other interactions.

Gathering in groups to transmit specialised knowledge, both pigeon flyers and singers sustained a particular gendered and historically shaped ethos, whether 'expressed (as attitudes, beliefs, values) or realised (as practices, goals)'. ${ }^{52}$ How were these pursuits

50. Narayan, Everyday Creativity, p. 99.

51. Wilkinson-Weber, Embroidering Lives, p. 133.

52. Stebbins, Serious Leisure, p. 12. 
and the emergent groups viewed from without? We have so far depicted shauq from the perspective of insiders revelling in their activities, and we now turn to other, less celebratory, views on shauq.

\section{The limits of shauq}

On a return visit to Kangra, Narayan was describing some of the contents of the ethnographic book to a singer while a wide-eyed daughter-in-law looked on, having brought out tea. While the singer had been a friend for three decades, Narayan did not really know the daughter-in-law, who was probably in her early twenties. Attempting to include her in the conversation, Narayan asked: 'Is singing your sukinni too?' The young woman shook her head no. Narayan tried again: 'What is your shauq?' There was an awkward pause. 'I don't have any shauq', the woman muttered, clearly mortified.

At the time, Narayan didn't press the conversation, but she could not help puzzling over this admission, contrasting it with Urmilaji's assertion, quoted earlier: 'As long as there as there is life, everyone will have some sort of sukinni'. Could it be that the younger woman simply did not have any passion with its associated emotional richness? Since a shauq could reveal so much about a person's distinctive sources of delight and chosen imaginative domains, was this question from a relative stranger simply too personal? Was this a case of familial deference, where admitting a shauq before a mother-in-law would somehow be viewed as not adequately caring for the welfare of a household? Might this absence be temporary, associated with a stage of life when the outward demands of child-rearing took priority over earlier personal interests (as singers sometimes acknowledged)? Or was this young woman afflicted by some kind of numbing sorrow from some other cause, such as the death of a beloved relative that singers also pointed to as damming their wellsprings of shauq?

This young woman's disavowal is a bracing reminder that a particular shauq might be disapproved of by outsiders, and is vulnerable to larger biographical circumstances and historical forces. Kavesh also observed that younger people caught up in the demands of standardised education said that they had no time to pursue a shauq. If they did have a diverting passion, it was unlikely to be confessed in the presence of a family elder. For someone who did not share the same shauq, a person's enthralled connection could be viewed as questionable, and indeed dangerous. If a person became too preoccupied, neglecting regular work and diverting resources from that work, shauq became 'bad' (bura, ganda); as an absorption that screened out other responsibilities, it was 'blind' (andha shauq).

Satyajit Ray's brilliant film, The Chess Players (Shatranj ke Khilari), based on a Hindi short story by Munshi Premchand, offers a dramatic illustration of the dangers of shauq. ${ }^{53}$ The story is set in the eighteenth-century kingdom of Awadh, where Wajid Ali Shah, 'besides ruling has all manner of shauq (jinhe raaj-kaaj ke alaava har tarah $k a$ shauq hai)'-for example, poetry, music and playing the part of Krishna among dancing girls. The film's central protagonists are two noblemen who 
obsessively return again and again to their chess games. Just as the kingdom's ruler is lost in his shauq, so too are the two friends lost in their chess. Regardless of the state of their marriages, of illness, or of death around them, regardless of war breaking out, court intrigues and the arrival of the British army, the two friends' world remains focused on the board before them. While offering an absorbing enclave, the diversion of shauq also exposed these enthusiasts to epoch-shifting politics beyond the horizon of their interest.

'When one takes up this shauq, one cannot leave it for his whole life', said Ustaad Jameel. He observed: 'just as all types of addiction ruin the addict's life, so can the shauq of flying pigeons'. As mentioned, Kangra women also sometimes jokingly referred to singing as a compelling addiction, like the need to drink tea or alcohol, but the South Punjabi pigeon flyers more soberly described their shauq as an addictive intoxication (nasha) and an incurable disease (bimaari). Put in these terms, shauq could be as deleterious as smoking, drinking, injecting heroin or using marijuana. Flyers also told the cautionary tale of Nawab Ishaq, an affluent local landowner who, through the second half of the twentieth century, had kept many pigeons, yet had crossed the boundary of shauq, allowing it to become an obsession (junoon): paying high prices for uniquely coloured and patterned pigeons, he slowly sold almost all his seventy acres of inherited agricultural land, and died a poor man, cursed by his sons.

Flyers faced criticism from their families and communities for prioritising pigeons over their families, for not taking life seriously, and for wasting money. Pigeon flying was seen as potentially destructive (draining resources and ancestral property), antiIslamic (diverting people from daily prayers in the mosque), a form of perversion (climbing around on rooftops, pigeon flyers might spy on unveiled neighbourhood women) and antisocial (with men withdrawing to keep company with their pigeons or with other flyers). Yet Rafiq, whose words started this paper, defended shauq when kept within limits. He said:

This shauq is not bad, but it gets a bad name (badnaam). It's the people who neglect their other work for flying pigeons who are ruining this shauq. They spend all day on rooftops and do nothing else. Because of these people, the public thinks that all pigeon keepers are idle people who don't really work. The shauq is to fly pigeons in the morning and do your work ( $\mathrm{kaam})$, and then return in the evening and fly pigeons again. Otherwise people will say, 'The pigeon flyer stays all day with his pigeons, and doesn't care about his work'. But I must tell you one thing, when a pigeon flyer remains with his pigeons, he gets intoxicated (nasha chadh jaata hai). He doesn't think about anything else, and when someone disturbs him, he is unhappy. If a guest comes to his house, he feels bad and says, 'I was just enjoying myself and now these guests have descended'.

As Rafiq said, the alignment of shauq with work and with responsibility appears to be crucial to its wider social acceptance. This perhaps explains why singing was not seen as a dangerous shauq. As women said, singing could be done while performing housework, and required only the voice and no external materials. A shauq threatens others when the pursuit diverts energy from other ties, demands resources, and so completely intoxicates people that they lose track of their other relationships. 
Focusing on the perspective of insiders, we have not attempted to locate the span of activities associated with shauq within a larger social field. Following Pierre Bourdieu's project in Distinctions to critically connect taste with class, ${ }^{54}$ one could similarly attempt to map the diversity of shauq-inspired activities around cultural and social hierarchies and probe the connection to social domination. For South Asia, intersectional hierarchies of class, caste, gender and generation shape the values accorded to particular shauq. We are only in a very limited way able to locate the particular domains of shauq discussed here in relation to other forms of shauq. Kavesh was able to situate pigeon flyers among the more aggressively masculine pursuits of cock fighting and dog fighting, noting that the gentle habits of pigeon flyers were seen as less masculine and more effetely linked to past courtly culture. Narayan observed how older women's songs in the local dialect performed in groups and usually without instrumentation were seen as archaic and even backward in contrast to the shauq of younger singers for songs in Punjabi and Hindi, sometimes learned from radio and television. Despite the centrality of pigeon flying and of singing traditional songs in the ruralbased lives of those we worked with, these activities are increasingly considered oldfashioned, and less attractive-the shauq of the older generation.

Nita Kumar has brilliantly traced the historical transformation of shauq and other cultural ideals in one location. Writing in the 1980s, she showed how elites in Banaras had been abandoning many popular forms of shauq. Activities like going to seasonal music festivals, organising poetry and music competitions, working out in wrestling gymnasia, and outdoor trips were now linked to illiteracy ${ }^{55}$ and dismissed by the rich as 'idleness', 'ignorance' and 'backwardness'. ${ }^{56}$ Instead of elites, people seen as lower class claimed the city's traditional cultural life as their special quality, and carried it on as their shauq. As Kumar forcefully notes, such change in how people choose to spend their energy and leisure time is tied to a 'fundamental culture change: change, that is, in basic cognitive categories' ${ }^{57}$

\section{Conclusion}

Working from an intersection in our respective fieldwork projects, we have sought to illuminate larger patterns around shauq as a conceptual category in South Asia. Yet, clearly, the force of shauq is encountered beyond the field as well. The fellow graduate student who turns out to be an accomplished chef; the renowned academic who is an aficionado of Hindustani classical music; the friend's teenage child whose hours at the computer turn out to be devoted to the writing of fan fiction-all these are examples of the ways in which, 'for fun', individuals spend time and effort to gain specialised knowledge, skill and expertise. As we conclude this essay, we invite readers to keep their own quirky interests and close-by examples in mind.

What does the concept of shauq offer scholars? Methodologically, our own enthusiasm for studying the shauq of others helped us establish and strengthen relationships.

54. Pierre Bourdieu, Distinction: A Social Critique of the Judgement of Taste, Richard Nice (trans.) (Cambridge: Harvard University Press, 1984).

55. Kumar, The Artisans of Banaras, p. 232.

56. Kumar, 'Work and Leisure in the Formation of Identity', p. 163.

57. Kumar, 'Open Space and Free Time', p. 58. 
Our mentors took on our education on their terms, sharing the aesthetic intricacies of their practices. To rephrase this in Tim Ingold's terms, this mode of learning affirms the project of anthropology as 'not a study of at all, but a study with' ${ }^{58}$ Such collaborative learning through shauq allows for a fine-grained ethnography of a subculture, while also allowing different theoretical directions to emerge from the materials. So, in longer works, we have elaborated on shauq differently. Narayan has followed metaphors within Kangra songs and what women taught her about their sukinni or shauq of singing to reflect on life-affirming aspects of everyday creativity. ${ }^{59}$ Kavesh's interactions with pigeon flyers-as well as cock fighters and dog fighters-led him to explore how different modalities of human-animal relations express honour and masculinity; shauq thus offered insights into more-than-human sociality. ${ }^{60}$ In this essay, he has chosen to focus on the pigeon flyers he has known for the most time (having first worked with them during his Master's thesis in 2007-08), and also because, of the three groups, they emphasised shauq the most, offering extensive commentaries and proverbs.

While the literature on shauq in South Asia affirms that such enthusiasm is usually cultivated within gendered social groups, for the purposes of this essay, we have focussed on continuities in the ways that women and men alike testify to the importance of shauq. Located at a tangent to a person's primary identity or form of livelihood, the concept of a personal shauq opens up space for individuals to follow predilections beyond their expected roles. Shauq affirms the value of cultivating aesthetic delight and emotional well-being over pragmatic financial concerns. Offering individuals the chance to savour beauty, to lose themselves in a chosen task, to acquire specialised knowledge and to gain respect for expertise, shauq is invaluable to enthusiasts.

The affinity of a shared interest draws people together. Shauq affirms and generates sociality through the vertical transmission of knowledge across generations and through the sometimes formalised roles of teacher and disciple; equally shauq gathers fellow enthusiasts together in horizontal and often levelling connections. Following a shauq can connect people beyond their usual social interactions-sometimes in formalised relationships and associations, sometimes in unstructured connections. In potentially stretching ascribed identities and established social structures, the pull of shauq can affirm commonalities across social difference.

Shauq is also perceived as dangerous. Cultivating one's own passions can be at best distracting and at worst outright disruptive to expected duties and responsibilities. As an idiosyncratic obsession, shauq can come close to an addiction and can destroy enthusiasts who show no restraint. Also, revealing affinity for a particular shauq is to potentially locate oneself in a larger span of shauq-driven activities with very particular connotations of class, caste, gender, generation and other hierarchies. Perhaps other ethnographers may attempt a larger mapping of all shauq and their associated cultural capital in a particular locale at a particular moment in time. As we have learned, the

58. Tim Ingold, Being Alive: Essays on Movement, Knowledge and Description (London/New York: Routledge, 2011), p. 238.

59. Narayan, Everyday Creativity.

60. Muhammad Kavesh, 'Beyond Cage and Leash: Human-Animal Relations in Rural Pakistan', PhD thesis, 2018, Australian National University, Canberra. 
nuances of shauq shift with location and with history. In a rapidly changing South Asia, our studies, limited to face-to-face interactions with communities in villages, could be usefully supplemented by future work on technologically mediated and consumption-driven expressions of shauq.

The domains elaborated through the pull of shauq might at first glance appear to be spaces of such light-hearted pleasure that they could be dismissed as irrelevant distractions from the larger inequalities, economic circumstances and environmental crises framing people's lives. Yet such activities, pursued with vibrant enthusiasm, can help make life worth living amid often difficult and rapidly transforming circumstances. For enthusiasts, these are priceless pursuits.

\section{Acknowledgements}

In addition to the many articulate people who shared their insights about shauq, for this essay we thank the patient family members and friends who helped bring it into form: Didi Contractor, Ken George, Marian Goad, Chris Gregory, Ian Holland, Shamim Homayun and Zara Shehzad. We also thank Assa Doron for inspiration and Benny Tong for introducing us to the concept of 'serious leisure'. We are grateful to Kama Maclean for her editorial role and the two South Asia reviewers for their extensive comments. Narayan gratefully acknowledges support from the American Institute of Indian Studies, the National Endowment for the Humanities, the John Simon Guggenheim Memorial Foundation, the Social Science Research Council and the University of Wisconsin-Madison. Kavesh acknowledges support from the Australian government's Department of Education and Training through the Endeavour Awards.

\section{Disclosure statement}

No potential conflict of interest was reported by the authors.

\section{Funding}

Endeavour Award, Department of Education and Training, Australia [PGPhD_DCD_3932_2014]. 